\title{
U.S. Drug Policy and Supply-Side Strategies: Assessing Effectiveness and Results
}

La política antidrogas de Estados Unidos y las estrategias de control de oferta: una evaluación de su efectividad y resultados

\author{
Michelle KeCK ${ }^{*}$ \\ Guadalupe Correa-CABrera ${ }^{* *}$
}

\begin{abstract}
The illegal drug trade in North America continues to prosper despite a 45-year war on drugs. Border enforcement is a key U.S. policy tool for preventing the flow of illegal drugs, and the U.S.-Mexico border has become the frontline in the war. Several scholars have questioned the ability of states, with their inflexible bureaucracies, tight budgets, and electorates, to effectively stop drug trafficking networks, which have considerable advantages, including flexibility, transnational connections, and market forces on their side. This article uses statistical data to determine if border enforcement along the southern U.S. border influences the illegal drug supply.
\end{abstract}

Key words: border enforcement, drug trafficking, war on drugs, U.S.-Mexico border

\section{RESUMEN}

El tráfico ilegal de drogas en Norteamérica sigue prosperando a pesar de una guerra contra las drogas de cuarenta y cinco años. La seguridad fronteriza es una estrategia clave de Estados Unidos para la prevención del tráfico de drogas ilegales. Algunos académicos han cuestionado la capacidad de los Estados, limitados por sus burocracias inflexibles, presupuestos restringidos y electorados, para detener efectivamente las redes del narcotráfico, las cuales cuentan con ventajas significativas, entre ellas una gran flexibilidad, conexiones transnacionales, así como con el apoyo de las fuerzas del mercado. Este artículo utiliza información estadística para determinar si la seguridad fronteriza a lo largo de la frontera sur de los Estados Unidos afecta la oferta de drogas ilegales.

Palabras Clave: seguridad fronteriza, tráfico de drogas, guerra contra las drogas, frontera México-Estados Unidos.

\footnotetext{
*Assistant professor of the Government Department, University of Texas at Brownsville, michelle.keck@utb.edu.

** Associate professor and chair of the Government Department, University of Texas at Brownsville, gcorrea75@ gmail.com.
} 


\section{INTRODUCTION}

The U.S. government relies on interdiction, including border inspections and border patrols, to disrupt the flow of drugs. In the practical sense, interdiction can be referred to as "seizure of drugs and smugglers as they travel from the source countries to the United States" (Reuter, Crawford, and Cave, 1988: 7). Border enforcement is a key component of interdiction efforts. Accordingly, the size and budgets for agencies in charge of it have increased considerably. For example, between 1993 and 1997, U.S. Customs Service funding earmarked for the southwest border grew 72 percent, and the size of the U.S. Border Patrol doubled between 1993 and 2000 from 4000 to over 9000 agents (Andreas, 2000: 51). The number of border patrol agents has continued to grow, reaching a historic high of over 21000 in 2013 (U.S. Customs and Border Inspection, 2014). In the past nine years, investment in border security has exceeded U.S. $\$ 100$ billion, and, from 2004 to today, the Border Patrol has more than doubled its number of agents. ${ }^{1}$ The number of Customs and Border Protection (Свр) officers, ICE agents and other federal law enforcement agents (including U.S. Marshals and Drug Enforcement Administration officials, among others), and various state and local law enforcement agents deployed to U.S. borders has increased significantly in the past few years. Congress has also massively expanded spending on fencing, infrastructure, and technology to secure the border.

This expansion in border enforcement is especially the case along the 2000-mile U.S.-Mexico border where, since the end of the 1990s, more U.S. Border Patrol agents were stationed in Brownsville, Texas, than along the entire 4 000-mile U.S.-Canadian border (Andreas and Nadelmann, 2006: 168). Presently, the number of "boots on the ground" along the Southwest border stands at more than 18500 Border Patrol agents (U.S. Customs and Border Inspection, 2014); interdiction policy complements this. Actually, interdiction policy and border enforcement focus on the supply side of the drug problem and are designed to increase the price of drugs, which is thought to reduce availability and demand. Notable and highly visible interdiction efforts along the U.S.-Mexico border, such as Operation Hard Line and Operation Brass Ring, as well as the involvement of the U.S. military, are all part of an effort to reduce the supply of drugs reaching their illicit market in the United States. The policy focuses on the border, the so-called source of the problem.

In spite of all the resources devoted to interdiction efforts on the border, questions about their effectiveness have been raised for the past couple of decades. In 1989, a General Accounting Office report to the Senate argued that interdiction had failed,

${ }^{1} 2004$ is the first year for which complete CBP data are available. 
with seizures having little impact on the drug problem. ${ }^{2}$ In a 1993 Senate subcommittee hearing on drug interdiction on the border, it was noted that, "interdiction has not had and is unlikely to have a significant impact on the national goal of reducing drug supplies to the United States" (Bertram et al., 1996: 20). In spite of recent efforts to fortify the border, some estimates show that only 10 percent of illegal drugs are intercepted at official U.S. ports of entry, with the remainder passing through into the United States (Staudt and O'Rourke, 2013: 225). ${ }^{3}$ On March 13, 2014, General John Kelly, head of the U.S. Southern Command, testified at the U.S. Senate Committee on Armed Services and mentioned that perhaps only 20 percent of the drugs coming from Colombia are intercepted (Senate Armed Services Committee, 2014). A recent study that examined international government drug surveillance databases found a drop in the price of illegal drugs and an increase in potency, despite a higher number of drug seizures by government agencies. This led the authors to conclude that "the global supply of illicit drugs has likely not been reduced in the previous two decades" (Werb et al., 2013: 7).

A number of scholars, past and present, have examined the effectiveness of supplyside reduction efforts (Moore, 1979; 1990; Reuter, 1988a, 1988b) by using various measurements. Moore (1990), for example, found that supply-side reduction efforts cut the price of marijuana and heroin, but not that of cocaine. ${ }^{4}$ A study by Reuter (1988a) indicates that interdiction does little to reduce cocaine consumption in the United States. Studies by Rhodes, Hyatt, and Scheiman (1994) and Nadelmann (1989) found that cocaine and heroin prices fell sharply through most of the 1980s. It is believed that interdiction has not had an impact on the price of cocaine because the costs and profits made by smugglers only account for 10 percent of the retail price once it crosses the border (Reuter, Crawford, and Cave, 1988). While these studies provide important information on how supply-side efforts impact the drug trade, they fail to isolate the specific effect that border enforcement has on this illicit activity.

Other scholars have discredited supply-side reduction efforts arguing that they have failed due to government's inability to understand how transnational drug trafficking organizations operate. Williams (1998) claims that the adoption of network structures by drug trafficking organizations has given them the flexibility for them to adopt new strategies so that they can stay in front of law enforcement efforts to dis-

\footnotetext{
${ }^{2}$ The name of the General Accounting Office, along with some of its functions, changed in 2004, and was replaced with the Government Accountability Office. So, for reference purposes, "GAO" references are for the Government Accountability Office, while the U.S. General Accounting Office entries will be found under that name. [Editor's Note.]

${ }^{3}$ It is difficult to accurately calculate this percentage. Different sources vary in their estimations, but most agree that this number is relatively small.

${ }^{4}$ More recent studies on this issue can be found in Payan, Staudt, and Kruszewski (2013).
} 
able their operations. According to Williams, networks afford them advantages like having a core and periphery, an ability to flow around physical barriers, a capacity to collect information on law enforcement initiatives, the use of multiple jurisdictions to move profits, and the capability to move between illegal and legal sectors through bribery, coercion, and intimidation. Williams also argues that law enforcement bodies engaged in supply reduction need to recognize drug trafficking organizations as networks and adopt network characteristics themselves in order to succeed. Scholars have also questioned governments' ability to win the war on drugs in an increasingly globalized world. Naim (2003) argues that governments face difficulties in stopping drug trafficking due to the fact that these crimes are not bound by geography, defy sovereignty, position the government against market forces, and place inflexible government bureaucracies in opposition to flexible drug trafficking networks.

Utilizing U.S. Border Patrol linewatch data, which represent the number of hours that U.S. Border Patrol agents spend in different lines of activity, including traffic observation, transportation check, and traffic check, this analysis seeks to determine the impact of border enforcement on illegal drug trade. More specifically, this article seeks to test the relationship between border enforcement, drug seizures, and drug prices in order to gauge if border enforcement is an effective supply-side reduction strategy.

The following section provides a history of U.S. interdiction policy, focusing on efforts along the Southwest border. Subsequently, we examine theory and policies concerning supply-side strategies and introduce hypotheses to determine the effectiveness of border enforcement. Then ee test the proposed relationships, and the final sections present our study findings and concluding remarks.

\section{A History of U.S. Interdiction Policy}

U.S. interdiction policy first emphasized border enforcement beginning with Nixon's 1971 "war on drugs." ${ }^{5}$ At the same time, Nixon's legacy was to shift attention abroad, setting his sights on drug policy as a component of U.S. foreign policy. Nixon called for a supply-side reduction policy, in other words, he proposed "to strike at the 'supply' side of the drug equation -to halt the drug traffic by striking at the illegal producers of drugs, the growing of those plants from which drugs are derived, and trafficking in these drugs beyond our borders" (Nixon, 1971: 95). Consequently, the administration implemented Operation Intercept, which employed 2000 agents along the U.S.Mexican border to conduct Border Patrol efforts described in official reports as "the

\footnotetext{
${ }^{5}$ President Nixon declared a "war on drugs" in June 1971 and signed it into law on January 28, 1972.
} 
country's largest peacetime search and seizure operation by civil authorities" (Bertram et al., 1996: 107).

The Reagan administration ushered in an intensification of U.S. interdiction policy when the president announced a new "war on drugs" in his second term and classified illegal drugs as a national security threat (Andreas, 2000). Cocaine and marijuana were being trafficked through the Southeast, and, in response, the administration created the South Florida Task Force to target air and sea cocaine smuggling routes from the Caribbean to South Florida, in order to reduce supply. The U.S. military was utilized for the first time to assist the Coast Guard and U.S. Customs Service in their efforts. These activities successfully reduced the flow, and the use of radar limited drug traffickers' ability to smuggle by air. ${ }^{6}$ Although U.S. officials declared the efforts a victory, Andreas (2000) indicates that these actions merely redirected the flow of cocaine to ground routes, particularly to the Southwest through Mexico.

In response to this unintended consequence, the administration turned its focus to the Southwest, launching Operation Alliance to coordinate military and civilian interdiction activities on the U.S.-Mexico border. As Andreas (2000) notes, the strategy for the Southeast was replicated in the Southwest and involved providing additional financing to enhance Border Patrol and Customs presence. As stated by Coast Guard Admiral Paul Yost in testimony before the House Select Committee on Narcotics, "The more money that you spend on it, the more success you are going to have in the interdiction area" (Yost, 1986). The stepped-up drug checks at points of entry and beyond acted to slow commerce, which sparked the concern of many in the private sector. In response, the Customs Service initiated the Southwest Border Strategy designed to improve the flow of legal cargo while prohibiting illegal cargo.

The 1990s marked a turning point in which enforcement along the U.S.-Mexico border dramatically increased. This escalation was directly related to the "successful" interdiction efforts in the Southeast, which resulted in a significant increase in drug traffic to the Southwest border. In response to the heightened traffic, the region was classified as a High Intensity Drug Trafficking Area in 1990. Consequently, the size of the U.S. Border Patrol doubled between 1993 and 2000, while the budget of the Immigration and Naturalization Service nearly tripled (Andreas and Nadelmann, 2006: 166). By 2001, 9000 agents were patrolling the 2 000-mile-long U.S.-Mexican border compared to 334 agents assigned to police the 4 000-mile-long U.S.-Canadian border (Andreas and Nadelmann, 2006). The U.S. military also got involved in border enforcement policy through the Department of Defense's establishment of the Joint Task Force North at Fort Bliss, which provides military support to law enforcement to stem illegal drug trafficking.

${ }^{6}$ See Payan (2007). 
In addition, a number of highly concentrated and highly visible border enforcement operations were implemented to secure the border from illegal drugs, particularly in light of the coming into effect of the North American Free Trade Agreement (NAFTA) in 1994, which sparked fears of increased drug trafficking through commercial cargo into the United States. In 1995, Operation Hard Line stepped up efforts to limit drug trafficking in commercial cargo, allocating approximately US\$65 million to support interdiction efforts along the Southwest border. In fiscal year 1997, the budget increased considerably to create 657 additional positions to protect the border, to fortify port-of-entry infrastructure, and for the use of high-tech equipment, such as X-ray facilities that could examine commercial transportation (U.S. Office of Federal Drug Control Policy, 1998). However, low cocaine seizure numbers led to an outcry in Congress and resulted in Operation Brass Ring, initiated in February 1998, to substantially increase drug seizure numbers in commercial cargo through an increased reliance on technology, including X-ray machines. The Brass Ring operation had jurisdiction over the 301 U.S. ports of entry and consisted mainly of "Jump Teams," which would arrive unannounced at the port of entry and select a certain number of containers for intense inspection. This operation came to an end July 31, 1998. It should be noted that in addition to these two programs' limited achievements, they both spawned concern in the trade community, which saw further inspections as a threat to rapid transport (Hall, 1998).

Today, the presence of law enforcement on the U.S.-Mexico border is at historic levels. The Border Patrol's "prevention through deterrence" strategy, which involves increased numbers of Border Patrol agents, use of surveillance technology, and fencing, is designed to push drug smugglers and illegal immigrants toward more hostile and difficult terrain. This has resulted, as already mentioned, in a steady increase in the number of agents stationed at the Southern border. Prevention through deterrence has also led to an evolution in surveillance technology in the interdiction effort with the use of unarmed drones. The United States has begun to make use of high altitude Global Hawk drones along its border with Mexico. This permits the U.S. and Mexico to gather intelligence on drug trafficking organization, allowing them to locate and monitor drug smugglers' activities. However, on December 24 2014, a report by the Office of the Inspector General found that after eight years, the USCBP Unmanned Aircraft System Program has not achieved its main goals. The report concluded that the cost per flight hour rose to US\$12 255 and that the СвP had not been able to properly assess this program's cost and effectiveness (Office of the Inspector General, 2014).

Additionally, Customs and Border Protection has built barriers to stem the flow of drugs as a result of the Secure Border Initiative (SBI). SBI policies include the construction of a US\$3-billion, 670-mile-long wall along the Southwest border from Browns- 
ville, Texas, to San Diego, California, as well as the creation of a US\$1.6-billion virtual fence, known as SBInet, in Arizona (Perez-Trevino, 2010) in an effort to reduce the flow of people and drugs across the border. As of 2005, just over 80 miles of federally enforced barriers and fencing were built at strategic points on the border, mainly in Texas and California. Additionally a Senate Committee hearing on Homeland Security and Governmental Affairs found that, as of April 2010, sBInet capabilities were not yet up and running. The General Accountability Office found that the lack of specificity in the program's objectives had had a negative impact on its application (GAO, 2010). A DHS assessment of the Secure Border Initiative found that "SBInet is not the most efficient, effective and economical way to meet [the] nation's border security needs" (DHS, 2011).

\section{SUPPLY-SIDE REDUCTION}

The primary theory that underscores most aspects of U.S. drug policy is the economics of supply. The economics of supply theory seeks to determine the impact that crop eradication, legal prohibition, and enforcement of transit restrictions have on the illegal drug supply (Wisotsky, 1983; Reuter and Kleiman, 1986). Utilizing comparative statistics, this approach contrasts the drug industry's structure, behavior, and performance in an illegal market with its performance in a legal market. The level of enforcement or legal barriers in an illegal market is expected to alter the supply and price. Given its economic roots, this theory is informed by the basic laws of supply and demand, such that an illegal market will supply fewer drugs for any given price and charge a higher price when compared to a legal market.

These forces will become even more prevalent with aggressive enforcement due to the fact that suppliers will drive up prices as a result of greater risk. Since this theory relies on supply and demand, the potential always exists for actors in the market to adjust to enforcement or legal restrictions, making it difficult to assess the long-term impact of supply-side reduction efforts. This is very apparent regarding border enforcement with successful U.S. interdiction efforts in the Southeast that eventually relocated drug traffic to the U.S.-Mexico border.

Several policies currently undertaken by the U.S. government, utilizing the logic of the economics of supply, include "activities conducted to divert, disrupt, delay, intercept, board, detain or destroy, under lawful authority, vessels, vehicles, aircraft, people, cargo and money" (Chairman of the Joint Chiefs of Staff, 2011), striking at the source, arresting drug traffickers and users, and stopping drugs at the border. Each policy concentrates on the three stages in the illegal drug trade and is designed 
to reduce drug production and availability. A brief examination of these policies will highlight variations among them.

At the source, supply reduction policies concentrate on striking at the root cause of the drug problem. This includes crop eradication, crop substitution, and treaty negotiation. Several scholars criticize these types of policies arguing that they are unable to affect prices reliably. Moore (1990) contends that strike-at-the-source policies are ineffective due to the fact that the U.S. must rely on the actions of foreign governments. Nadelmann (1989) argues that eradication efforts are problematic because marijuana, opium, and coca can be grown in a large number of places, creating new producers, and that growers will utilize guerilla-farming methods to plant crops in inaccessible areas. In addition, Farrell (1998) found that crop eradication, even when accompanied by crop substitution or alternative development, has had a minimal effect on the production of illicit drugs.

A second commonly used supply reduction policy involves law enforcement efforts criminalizing users along with traffickers. A number of scholars (Reuter and Kleiman, 1986; Caulkins and Reuter, 2010) have examined how enforcement efforts can affect price. Reuter and Kleiman (1986) argue that enforcement imposes costs on drug dealers and these costs are passed to the consumer. Caulkins and Reuter (2010) find that a base level of enforcement drives prices up above the legalized price; however, they conclude that in established markets, expanding enforcement past the base level is a costly way to drive up the price.

One of the final supply-reduction policies, interdiction, essentially stopping drugs at the border, is the subject of this study. U.S. Border Patrol and Customs officials engage in inspections to interdict drug shipments headed to U.S. markets. Of all the supply-reduction policies utilized by the U.S., Moore (1990) indicates that interdiction has grown the fastest. The border does allow for unique legal powers regarding searches and seizures, with seizures being one of the ways in which success of interdiction is measured. Interdiction is also expected to influence the price of illegal drugs by reducing the amount available for consumption (Moore, 1990).

Scholars have raised questions regarding the ability of interdiction to disrupt the drug supply and price, resulting in mixed findings. Reuter (1988a) argues that in spite of an increase in cocaine seizures in the 1980s, total imports continued to increase and the price of cocaine at the import and retail level fell significantly. His study indicates that even a 50-percent reduction in the Latin American cocaine supply would increase the street price only 3 percent due to the fact that the value added to drugs occurs after they cross the border, highlighting the impact of local law enforcement.

Using a simulation model that captures how drug cartels adapt to increased interdiction efforts, Reuter, Crawford, and Cave (1988: 11) find that, as seizures in- 
crease, the total cost of getting drugs from the source country to the U.S. increases only slightly due to the small share of drug distribution costs from the smuggling phase of the operation. The authors conclude that interdiction has little to no effect on the price of cocaine since cost and profits for smugglers only amount to 10 percent of the overall price (Reuter, Crawford, and Cave, 1988: 11).

Moore (1990) indicates that interdiction appears to affect the price of marijuana due to the fact that it is bulkier and more likely to be shipped in non-commercial vehicles. Nadelmann (1989) also indicates that interdiction has been successful at reducing the supply of marijuana and has increased its price. However, this has resulted in smugglers switching from trafficking marijuana to the less bulky cocaine. Heroin has often been touted as the least likely drug to be seized due to the fact that it is typically not imported in large quantities and is usually trafficked by individuals who swallow it or conceal it internally in body cavities (Jurkanin and Hillard, 2006). This raises questions about the impact interdiction efforts have on increasing the price of heroin (Bertram and Sharpe, 1996).

The mixed findings in the literature give rise to this article, which seeks to assess the effectiveness of interdiction efforts by examining the relationship between border enforcement, drug seizures, and drug prices. Using U.S. Border Patrol linewatch data as a measure of border enforcement, which record the number of hours agents spend policing land borders and ports of entry along the U.S.-Mexican border, the following hypotheses are proposed:

H1: Border enforcement will be negatively related to the amount of cocaine seized.

H2: Border enforcement will be positively related to the amount of marijuana seized.

H3: Border enforcement will be negatively related to the amount of heroin seized.

H4: Border enforcement will be positively related to the price of marijuana.

H5: Border enforcement will be negatively related to the price of cocaine.

H6: Border enforcement will be negatively related to the price of heroin.

\section{Data And Methods}

To determine the impact that interdiction at the border has on the illegal drug market, we analyze data from the years 1996-2003, for a total of eight years of observations. These dates are important for a number of reasons. As noted earlier, interdiction efforts along the southwest border increased dramatically in the early 1990s, making the period an important test for border enforcement policies. In addition, these years include 9/11 and its aftermath, an effect that resulted in increased appropriations for the Border Patrol. 
The variables of interest in this analysis include border enforcement, which is operationalized using U.S. Border Patrol data on linewatch hours on the U.S.-Mexico border. Linewatch hours provide a good proxy for border enforcement, since they are a measure of the number of hours per year the U.S. Border Patrol spends in activities including traffic observation, transportation check, and traffic check.

Data on drug seizures is taken from the 1997 Office of National Drug Control Policy Report on the Southwest border region and a 2007 GAO report on U.S. interdiction efforts on the Southwest border and are presented in Table 4. The data sources provide the annual amount of cocaine, heroin, and marijuana seized along the Southwest border in metric tons. ${ }^{7}$ Logs of each variable are taken into account for extreme values of the seizure variables which are skewed, creating a non-linear relationship. To control the skew and to counter problems of heteroskedasticity, we transform the seizure variables by taking their logarithm.

Data on cocaine, heroin, and marijuana prices are obtained from the $2005 \mathrm{Na}$ tional Drug Control Strategy Data Supplement, which uses price data from the DEA System to Retrieve Information on Drug Evidence (STRIDE). STRIDE provides lab analyses of street-level drug purchases. The data used in this article measures purchases greater than 10 grams, which the DEA classifies as purchases at the dealer level. In order to control for inflation, the price data has been converted to 2003 U.S. dollars. ${ }^{8}$

To assess the relationship among the variables of interest, we used bivariate regression analysis. It is worth mentioning that the choice of method may limit the relevant findings, since control variables that could also influence the dependent variables are not being considered, such as international efforts, including crop eradication and substitution, international enforcement agreements and treaties, as well as state and local drug enforcement, including the number of drug-related arrests, resulting in omitted variable bias. Nevertheless, this study is an attempt at an initial understanding of how border enforcement impacts critical variables related to the illegal drug trade. Table 1 presents the summary statistics for the variables used in the study.

\footnotetext{
${ }^{7}$ The 2007 GAO report indicates that hundreds of tons of cocaine, heroin, and marijuana arrive in the U.S. from Mexico every year, while seizures in Mexico and along the U.S. border are quite small. For example, since 2000, the estimated amount of cocaine arriving in Mexico for shipment to the U.S. is around 275 metric tons per year, while seizures averaged approximately 36 metric tons a year. The amount of exportquality heroin produced in Mexico is around 19 metric tons, with reported average heroin seizures coming to less than 1 metric ton annually. Marijuana produced in Mexico is estimated to be 9400 metric tons per year, with average marijuana seizures estimated at 2900 metric tons a year.

${ }^{8}$ Although questions have been raised about the accuracy of STRIDE data, including a study by Horowitz (2001), who argued that they were inconsistent because prices collected in Washington, D.C. by the DEA and MPDC were different, Arkes, Pacula, Paddock, Caulkins, and Reuter (2008) find that the differences are due to the agencies being involved in different distribution levels, with the DEA covering wholesale transactions while the MPDC covers retail transactions. The authors find no difference between the two agencies once they split the samples by distribution levels.
} 


\begin{tabular}{|lccrrc|}
\hline \multicolumn{5}{c}{ Table 1 } \\
Variables & Obs. & Mean & Std. dev. & Minimum & Maximum \\
Linewatch & 8 & 15.834 & .3201 & 15.238 & 16.098 \\
Cocaine seizures & 8 & 10.559 & .2232 & 10.275 & 10.833 \\
Marijuana seizures & 8 & 13.990 & .6517 & 13.210 & 14.805 \\
Heroin seizures & 8 & 5.984 & .6188 & 5.036 & 6.647 \\
Total drug seizures & 8 & 14.026 & .6359 & 13.270 & 14.819 \\
Cocaine price & 8 & 54.21 & 5.531 & 44.17 & 59.56 \\
Marijuana price & 8 & 6.94 & 1.550 & 5.23 & 9.30 \\
Heroin price & 8 & 189.11 & 54.359 & 139.22 & 289.04 \\
Source: U.S. Office of National Drug Control Policy (1997), GAO (2007), and U.S. National Drug \\
Control Strategy (2005).
\end{tabular}

\section{RESULTS}

The results, provided in the tables below, reveal some interesting findings regarding the effect of border enforcement on the illegal drug market.

\begin{tabular}{|lcc|}
\hline \multicolumn{3}{|c|}{ Table 2} \\
\\
BIVARIATE ANALYSIS OF BORDER ENFORCEMENT AND COCAINE SEIZURES
\end{tabular}

The results in Table 2 reveal a positive relationship between border enforcement and cocaine seizures. A one-unit increase in the number of linewatch hours spent by U.S. Border Patrol on the U.S.-Mexico border results in a 0.4528 increase in cocaine seizures. This finding disconfirms hypothesis one. Given that cocaine is not very 
bulky, one could argue that it may be less likely to be detected by border agents; however, the results indicate a positive relationship between enforcement hours and cocaine seizures.

Although border enforcement is positively related to cocaine seizures, questions remain regarding how effective seizures are regarding cocaine prices, which is why the policy is pursued. The General Accounting Office noted this issue, concluding in a report that "the enormous profits in cocaine trafficking make interdiction losses relatively inconsequential. ... Given this huge profit margin, it appears unlikely that interdiction will be a significant cost deterrent to traffickers"' (Bertram et al., 1996: 20).

\begin{tabular}{|c|c|c|}
\hline \multicolumn{3}{|c|}{$\begin{array}{c}\text { Table } 3 \\
\text { BORDER ENFORCEMENT AND MARIJUANA SEIZURES }\end{array}$} \\
\hline & Marijuana seizure & $P$ value \\
\hline Border enforcement & $\begin{array}{l}1.683 \\
(.3485)\end{array}$ & $0.003^{* *}$ \\
\hline Constant & $\begin{array}{r}-12.673 \\
(5.446)\end{array}$ & $0.059 * *$ \\
\hline Observations & & \\
\hline $\mathrm{F}$ & $23.34^{* *}$ & \\
\hline $\mathrm{R}^{2}$ & 0.684 & \\
\hline
\end{tabular}

The results in Table 3 support hypothesis 2, which contends that border enforcement will be positively related to marijuana seizures. A one-unit increase in the number of linewatch hours increases marijuana seizures by 1.683 metric tons. Marijuana has historically been the most intercepted illegal drug, far exceeding the amounts of cocaine and heroin. Data from this study presented in Table 4 reveal the large disparities in the amount of drugs seized. Moore (1990) argues that one of the weaknesses of U.S. interdiction policy is the considerable focus on marijuana, which does appear to affect its price more than that of other illegal drugs. Nadelmann (1989) argues that marijuana interdiction success has led to unintended consequences, particularly in light of the fact that the U.S. has emerged as one of the world's leading producers of marijuana and is believed to produce some of the best and most potent strains globally. Indeed, the Arcview Market Research Group, a cannabis investment and research firm, reported an increase in the legal cannabis market in the United States of US\$1.2 billion between 2013 and 2014 (Ferner, 2015). 
Table 4

DRUG SEIZURES ALONG THE SOUTHWEST BORDER

(1996-2003 in Metric Tons)

\begin{tabular}{|cccc|} 
Year & Cocaine & Heroin & Marijuana \\
1996 & 33308 & 459 & 545922 \\
1997 & 30000 & 190 & 590000 \\
1998 & 29000 & 390 & 790000 \\
1999 & 42000 & 300 & 890000 \\
2000 & 50706 & 154 & 1175063 \\
2001 & 44092 & 771 & 2387606 \\
2002 & 50706 & 661 & 2663355 \\
2003 & 35273 & 771 & 2691844 \\
Source: U.S. Office of National Drug Control Policy (1997) and GAO (2007). & \\
\hline
\end{tabular}

Results regarding the influence of border enforcement on heroin seizures showed it was not significant. Heroin has often been touted as the least likely drug to be seized and the most difficult drug to interdict given the ease with which individuals can hide it. Data in Table 4 indicate the small amount of heroin seized along the U.S.Mexican border annually, particularly when compared to cocaine and marijuana.

\begin{tabular}{|c|c|c|}
\hline \multicolumn{3}{|c|}{$\begin{array}{c}\text { Table } 5 \\
\text { BIVARIATE ANALYSIS OF BORDER ENFORCEMENT AND HEROIN SEIZURE }\end{array}$} \\
\hline & Heroin Seizures & $P$ value \\
\hline Border enforcement & $\begin{array}{l}.1541 \\
(.1758)\end{array}$ & 0.414 \\
\hline Constant & $\begin{array}{l}14.911 \\
(1.084)\end{array}$ & $0.000 *$ \\
\hline Observations & 8 & \\
\hline $\mathrm{F}$ & $0.77 *$ & \\
\hline $\mathrm{R}^{2}$ & 0.088 & \\
\hline \multicolumn{3}{|c|}{$\begin{array}{l}{ }^{*} p>0.10,{ }^{* *} p<0.05,{ }^{* * *} p<0.01 ; \text { two-tailed tests; robust standard errors in parentheses. } \\
\text { Source: Developed by the authors using data from the U.S. Office of National Drug Control } \\
\text { Policy (1997) and GAO (2007). }\end{array}$} \\
\hline
\end{tabular}


Results regarding the relationship between border enforcement and illegal drug prices are presented in Tables 6-8, some of which are interesting. Although marijuana has been heralded as the most interdicted and, as a result, the most likely drug to be influenced in terms of price by border enforcement efforts, this study's results disprove hypothesis 4 , since no statistically significant relationship was found between border enforcement and the price of marijuana.

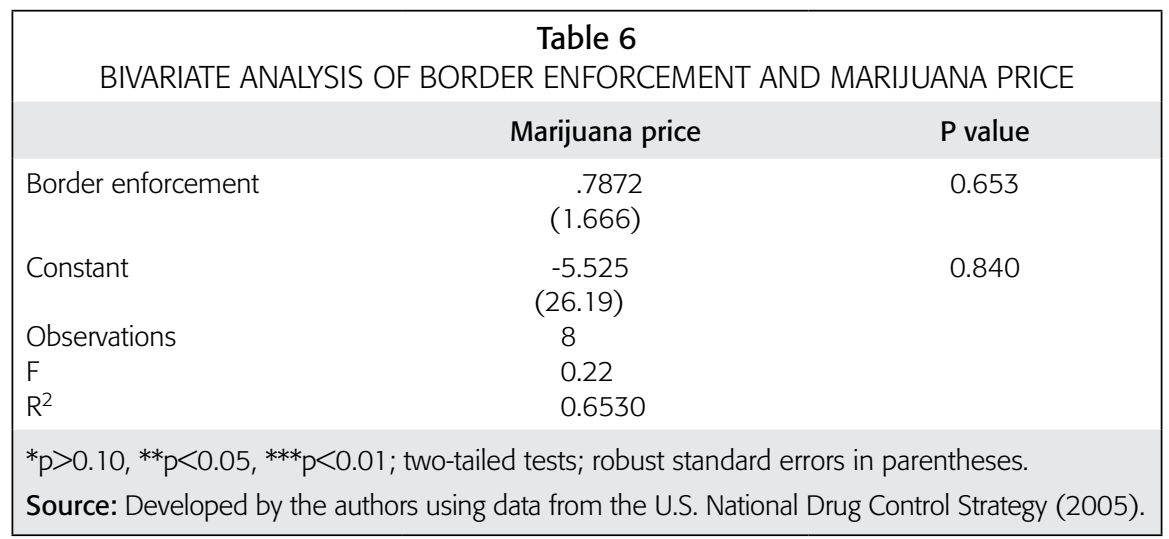

The results regarding the impact that border enforcement has on the price of cocaine and heroin do support hypotheses 5 and 6 and portend negative consequences for interdiction, in terms of its ability to affect cocaine and heroin prices. As indicated in Table 7, a one-unit increase in the number of linewatch hours reduces the price of cocaine in the U.S. by US\$9.54 per gram. This result supports Reuter's findings (1988a); he argues that the value of cocaine is added after it crosses the border, making interdiction efforts ineffective in terms of its influence on price.

\begin{tabular}{|lcc|}
\hline \multicolumn{1}{|c|}{ Table 7} \\
& BIVARIATE ANALYSIS OF BORDER ENFORCEMENT AND COCAINE PRICE \\
& Cocaine price & P value \\
Border enforcement & -9.541 & $0.072^{*}$ \\
& $(4.379)$ & \\
Constant & 205.296 & $0.023^{* *}$ \\
& $(67.892)$ & \\
Observations & 8 & \\
F & $4.75^{*}$ & \\
$\mathrm{R}^{2}$ & 0.305 & \\
${ }^{*} \mathrm{p}>0.10,{ }^{* *} \mathrm{p}<0.05,{ }^{* * *} \mathrm{p}<0.01$; two-tailed tests; robust standard errors in parentheses. \\
Source: Developed by the authors using data from the U.S. National Drug Control Strategy (2005).
\end{tabular}


The results for heroin support hypothesis 6 and indicate that a one-unit increase in the number of hours spent by U.S. Border Patrol agents in linewatch duties acts to decrease the price of heroin by US\$162.97 per gram. Scholars, including Bertram and Sharpe (1996), attribute the failure of interdiction policies influencing the price of heroin to advanced smuggling techniques that make detection difficult. Additionally, Moore (1990) argues that heroin and cocaine smugglers have alternative trafficking methods that are not as readily available to marijuana smugglers, including general aviation and shipments on commercial planes and ships.

\begin{tabular}{|lcc|}
\hline \multicolumn{4}{|c|}{ Table 8} \\
\\
BIVARIATE ANALYSIS OF BORDER ENFORCEMENT AND HEROIN PRICE
\end{tabular}

\section{ConCLUSION}

Our study is one of the first attempts at determining the influence that border enforcement has on the U.S. illegal drug market. The results shed some interesting light on the effect of border enforcement on the seizure and price of illegal drugs. A positive significant relationship was found between border enforcement and cocaine and marijuana seizures, with no significant effect found with regard to heroin seizures. No statistically significant relationship was found between border enforcement and the price of marijuana, contrary to assumptions in the literature; however, the results indicate that border enforcement is statistically significant and negatively related to cocaine and heroin prices, with an increase in border enforcement reducing the price of both drugs.

There are numerous difficulties in relying on border enforcement alone to fight illegal drugs, and the literature reveals the mixed record of success that interdiction has had on the illegal drug market. U.S. government officials have admitted the difficulty. In 1981, President Reagan noted, "With borders like ours, [interdiction] as the main method of halting the drug problem is virtually impossible... like carrying 
water in a sieve" (Reagan, quoted in Bertram et al., 1996: 22). In spite of these difficulties, interdiction efforts have not only continued, they have escalated, making it relevant to study the effectiveness of such an expensive supply-side reduction policy.

This study is a first look at this question, which needs to be further explored, in part by including recent data that would capture the impact of U.S. interdiction efforts on the Southwest border in light of the Mexican war on drugs declared by President Calderón in 2006, and the corresponding escalation of border enforcement by the U.S. Additional research into this topic would also involve expanding the model to consider border enforcement effectiveness, alongside other supply-side reduction policies, such as crop eradication and substitution, international drug enforcement treaties, and state and local law enforcement efforts, particularly in light of the changing attitudes on the utility and effectiveness of the war on drugs in the U.S., resulting in the decriminalization of personal amounts of illegal drugs in a number of states as well as the legalization of recreational marijuana in Colorado, Washington, Alaska, Oregon, and the District of Columbia. Furthermore, future plans would include collecting data on border enforcement, drug prices, and drug seizures for a longer period of time in order to determine the historical relationship, utilizing a multivariate time series vector autoregression (VAR) analysis.

\section{BIBLIOGRAPHY}

AndreAs, Peter

2000 Border Games: Policing the U.S.-Mexico Divide, Ithaca, New York, Cornell University Press.

Andreas, Peter, and Ethan Nadelmann

2006 Policing the Globe, Oxford and New York, Oxford University Press.

Arkes, Jeremy, Rosalie Pacula, Susan Paddock, Jonathan Caulkins, and Peter Reuter 2008 "DEA STRIDE Data Are Still Useful for Understanding Drug Markets," NBER Working Paper 14224, http: / / www.nber.org/ papers/w14224.pdf, accessed July 16, 2015.

BATES, ADAM

2015 "There Is Nothing Funny about Wanting to Halt the Drug War," http:/ / www.newsweek.com/theres-nothing-funny-about-wanting-halt-drug -war-315464, accessed June 29, 2015. 
Bertram, Eva, and KenNETH SHARPE

1996 “The Unwinnable Drug War: What Clausewitz Would Tell Us," World Policy Journal, vol. 13, no. 4, pp. 41-51.

Bertram, Eva, Morris Blachman, Kenneth Sharpe, and Peter Andreas

1996 Drug War Politics: The Price of Denial, Berkeley, University of California Press.

Caulkins, Jonathan, and Peter Reuter

2010 "How Drug Enforcement Affects Drug Prices," Crime and Justice, vol. 39, no. 1, pp. 213-271.

Chairman of the Joint Chiefs OF STAFF

2011 "Joint Interdiction" October, https://fas.org/irp/doddir/dod/jp3_03.pdf, accessed January 10, 2015.

DHS (U.S. DePARTMENT OF Homeland SECURITY)

2011 "Report on the Assessment of the Secure Border Initiative-Network (sBinet) Program," http:/ / www.globalexchange.org/sites/default/files/DHS_Report .pdf, accessed January 10, 2015.

FARRELL, GRAHAM

1998 "Global Empirical Review of Drug Crop Eradication and United Nations' Crop Substitution and Alternative Development Strategies," Journal of Drug Issues, vol. 28, no. 2, pp. 11-12.

FERNER, MATT

2015 "Legal Marijuana is the Fastest-Growing Industry in the U.S.: Report," http: / / www.huffingtonpost.com/2015/01 / 26/ marijuana-industry-fastest -growing_n_6540166.html, accessed January 27, 2015.

GaO (Government Accountability Office)

2010 "Secure Border Initiative DHs Has Faced Challenges Deploying Technology and Fencing Along the Southwest Border," http:/ / www.gao.gov/assets / 90 / 82411.pdf, accessed January 8, 2014.

2007 “U.S. Assistance Has Helped Mexican Counternarcotics Efforts, But the Flow of Illicit Drugs into the United States Remains High," http: / www.gao.gov/ new.items/ d08215t.pdf, accessed March 5, 2014. 


\section{HALL, KEVIN}

1998 “Operation Brass Ring No Bust, Customs Finds," http:/ / www.joc.com/operation -brass-ring-no-bust-customs-finds_19980806.html, accessed March 5, 2015.

HorOWITZ, JOEL

2001 "Should the DEA's STRIDE Data Be Used for Economic Analyses of Markets for Illegal Drugs?" Journal of the American Statistical Association, vol. 96, no. 456, pp. 1254-1271.

Jurkanin, Thomas J., and Terry G. Hillard

2006 Chicago Police: An Inside View-The Story of Superintendent Terry G. Hillard, Springfield, Illinois, Charles C. Thomas Publishing.

MOORE, MARK

1990 "Supply Reduction and Drug Law Enforcement," Journal of Crime and Justice, vol. 13, no. 18, pp. 109-157.

1979 "Limiting Supplies of Drugs to Illicit Markets in the United States," Journal of Drug Issues, vol. 9, no. 2, pp. 291-308.

NADELMANN, ETHAN

1989 "Drug Prohibition in the United States: Costs, Consequences, and Alternatives," Science, vol. 245, no. 4921, pp. 939-947.

NAIM, MOISES

2003 “The Five Wars of Globalization," Foreign Policy, vol. 134, pp.29-37.

NiXON, RichARD

1971 "President's Message on Drug Control Programs," Congressional Quarterly Almanac, 26, 95A.

Office of the Inspector General

2014 “U.S. Customs and Border Protection's Unmanned Aircraft System Program Does Not Achieve Intended Results or Recognize All Costs of Operation," http: / / www.oig.dhs.gov/ assets/Mgmt/2015/OIG_15-17_Dec14.pdf, accessed March 5, 2015. 
PAYAN, TONY

2007 Cops, Soldiers, and Diplomats: Explaining Agency Behavior in the War on Drugs, New York, Lexington Books.

Payan, Tony, Kathleen Staudt, and Anthony Kruszewski, eds.

2013 A War that Can't Be Won: Binational Perspectives on the War on Drugs, Tucson, University of Arizona Press.

Perez-Trevino, Emma

2010 "Costly Efforts to Secure Border Not Paying Off," http: / www.brownsville herald.com/articles/border-113498-secure-initiatives.html, June 19, accessed January 5, 2014.

Reuter, Peter

1988a "Can the Borders Be Sealed?" Public Interest, vol. 92, Summer, pp. 51-65, https: / / www.rand.org/content/dam/rand/pubs/notes/2005/N2818.pdf.

1988b “Quantity Illusions and Paradoxes of Drug Interdiction: Federal Intervention into Vice Policy," Law and Contemporary Problems, vol. 51, no. 1, pp. 233-252.

Reuter, Peter, and Mark Kleiman

1986 "Risks and Prices: An Economic Analysis of Drug Enforcement," Crime and Justice, vol. 7, http://faculty.publicpolicy.umd.edu/sites/default/files/re uter / files / Risks_and_prices.pdf, pp. 289-340.

Reuter, Peter, Gordon Crawford, and Jonathan Cave

1988 "Sealing the Borders: The Effects of Increased Military Participation in Drug Interdiction," http: / / www.rand.org/content/ dam/rand/pubs / reports / 2007/ R3594.pdf, accessed February 12, 2014.

Rhodes, William, Raymond Hyatt, and Paul Scheiman

1994 "The Price of Cocaine, Heroin, and Marijuana, 1981-1993," Journal of Drug Issues, vol. 24, no. 3, pp. 383-402.

\section{Senate Armed Services Committee}

2014 Hearing, "United States Northern Command (NORTHCOM) and United States Southern Command (SOUTHCOM) in Review of the Defense Authorization Request for Fiscal Year 2015 and the Future Years Defense Program (FYDP)," http: / / www.northcom.mil / Portals / 28 / Documents / Transcript $\% 20$ SASC\% 20 
NORTHCOM $\% 20$ SOUTHCOM $\% 20$ FY15\%20Budget $\% 20$ Gen $\% 20$ Jacoby $\% 20$ 03\%2013\%202014.pdf, accessed January 10, 2015.

Staudt, KathleEn, and Beto O’Rourke

2013 "Challenging Foreign Policy from the Border: The Forty-Year War on Drugs," in Payan, Tony, Staudt, Kathleen and Anthony Kruszewski, eds., A War that Can't Be Won: Binational Perspectives on the War on Drugs, Tucson, University of Arizona Press, 2013.

\section{U.S. Customs AND BORder Inspection}

2014 "Border Patrol Agent Staffing by Fiscal Year," http: / www.cbp.gov/ sites / default / files / documents / BP\%20Staffing\%20FY1992-FY2014_0.pdf, accessed January 5, 2015.

\section{U.S. General Accounting OfFice}

1998 "Drug Smuggling: Capabilities for Interdicting Private Aircraft Are Limited and Costly," http:/ / www.gao.gov/assets/150/147877.pdf, accessed March 5, 2014.

U.S. National Drug Control Strategy

2005 "Data Supplement," https: / / www.ncjrs.gov/pdffiles1/ondcp/213692.pdf, accessed February 5, 2014.

\section{U.S. Office of National Drug Control Policy}

1998 "An Overview of Federal Drug Control Programs on the Southwest Border, United States Customs Service," https: / / www.ncjrs.gov/ondcppubs/pub lications / enforce/border/uscs.html, accessed March 5, 2015.

1997 "Executive Office of the President of the United States, The Southwest Border Region in Context," http: / / www.hsdl.org / ?view\&did=233826, accessed January 12, 2014.

Werb, Dan, Thomas Kerr, Bohdan Nosyk, Steffanie Strathdee, Julio Montaner, and Evan WoOd

2013 "The Temporal Relationship between Drug Supply Indicators: An Audit of International Government Surveillance Systems," http: / www.bmjopen .bmj.com/content/3/9/e003077.full.pdf+html, accessed March 5, 2015. 
Williams, Phil

1998 "The Nature of Drug Trafficking Networks," Current History, vol. 97, no. 618, April, pp. 154-159.

WisOTSKY, STEVEN

1983 "Exposing the War on Cocaine: The Futility and Destructiveness of Prohibition," University of Wisconsin Law Review, November-December, pp.13051426.

Yost, PAUL

1986 "Testimony before the House Select Committee on Narcotics Abuse and Control," $99^{\text {th }}$ Congress, July 22, 1986, 34. Washington, D.C. 
